Riwayat draf artikel: Diserahkan 21-02-2021 Diterima 27-02-2021

\section{Korelasi Sertifikasi dan Motivasi Kerja terhadap Kinerja Guru di Masa Pandemi Covid-19}

Amruddin $^{1^{*}}$, Wresni Pujiyati ${ }^{2}$, Ipong Dekawati ${ }^{3}$

Magister Administrasi Pendidikan, Universitas Wiralodra

Email: namru01@gmail.com ${ }^{1^{*}}$, wresni.pujiyati@unwir.ac.id ${ }^{2}$, ipongdekawati@unwir.ac.id ${ }^{3}$

\begin{abstract}
ABSTRAK: Penelitian ini bertujuan untuk memperoleh deskripsi korelasi antara sertifikasi guru dan motivasi kerja guru terhadap kinerja guru di Sekolah Dasar Negeri Kecamatan Wanasari Kabupaten Brebes. Penelitian ini menggunakan pendekatan kuantitatif dengan metode analisis desskriptif. Sampel penelitian ini adalah guru bersertifikasi di sekolah dasar negeri yaitu sebanyak 45 guru yang berasal dari 18 Sekolah. Sampel ditentukan melalui Probability Sampling. Teknik pengumpulan data yang digunakan yaitu: studi dokumen dan angket. Hasil penelitian menunjukkan bahwa; 1) terdapat korelasi signifikan antara sertifikasi guru dengan kinerja guru; 2) terdapat korelasi signifikan antara motivasi kerja dengan kinerja guru; 3) terdapat korelasi signifikan sertifikasi guru dan motivasi kerja secara bersama-sama dengan kinerja guru.
\end{abstract}

Kata kunci: kinerja, motivasi, sertifikasi

ABSTRACT: The purpose of this analysis is to provide a summary of the relationship between teacher certification and teacher job encouragement at the Wanasari District Elementary School, Brebes District, for teacher results. This thesis takes a quantitative approach using the framework of descriptive analysis. Certified teachers in public elementary schools, up to 45 teachers from 18 schools, are a sample of this study. By Likelihood Sampling, the sample is determined. The tools used for data collection were: paper analysis and questionnaire. The findings suggest that; 1) there is a strong association between the qualification of teachers and the success of teachers; 2) there is a significant correlation between the incentive to work and the success of teachers; 3) there is a significant correlation between the qualification of teachers and the motivation to work along with the performance of teachers.

Keywords: certification, motivation, teacher performance

\title{
PENDAHULUAN
}

Sertifikasi guru merupakan sebuah program dimana guru akan dimonitoring dan diuji secara berkala dengan menggunakan alat uji yang telah ditetapkan pemerintah. Guru yang ideal dan layak akan mendapatkan sertifikat kelayakan mengajar sebagai bukti bahwa guru tersebut memang layak mengajar dan mendapatkan penghargaan yang pantas.

Sertifikasi guru akan menciptakan mampu sumber daya pengajar yang semakin baik. Hal ini disebabkan karena guru akan selalu berusaha untuk mampu mencapai batas kemampuan minimal yang diperlukan untuk sertifikasi. Dalam buku Sujanto (2009: 8-9) dijelaskan bahwa ada dasarnya pelaksanaan sertifikasi guru mempunyai banyak tujuan, yaitu: 1) Menentukan kelayakan guru sebagai agen pembelajaran; 2) Meningkatkan proses dan mutu pendidikan; 3) Meningkatkan martabat guru; 4) Meningkatkan profesionalisme. 
Guru sebagai pendidik profesional dengan tugas utama mendidik, mengajar, membimbing, mengarahkan, melatih, menilai, dan mengevaluasi peserta didik pada pendidikan anak usia dini jalur pendidikan formal, pendidikan dasar, dan pendidikan menengah (UU RI No. 14 Tahun 2005) tetap berkewajiban untuk melaksanakan tugasnya dengan berbagai penyesuaian, baik penyesuaian kebijakan maupun pelaksanaannya di lapangan pada era pandemi covid-19 dengan tetap merujuk pada Standar Nasional Pendidikan untuk mencapai tujuan pendidikan nasional.

Pandemi covid-19 mempunyai pengaruh di berbagai sektor, baik manufaktur maupun jasa, salah satunya adalah pendidikan (Debbarma, \& Durai, 2021). Surat Keputusan Bersama (SKB) Empat Menteri yaitu Menteri Pendidikan dan Kebudayaan, Menteri Agama, Menteri Kesehatan, dan Menteri Dalam Negeri tahun 2020 (kendikbud.go.id) memberikan kewenangan kepada pemerintah daerah terkait kewenangan pembelajaran di era pandemi covid 19 rumpun dasar dan menengah. Ini merupakan salah satu langkah untuk mengantisipasi pengaruh pandemi covid-19 terhadap kegiatan belajar mengajar di Indonesia.

Kinerja merupakan suatu kemampuan kerja atau prestasi kerja yang diperlihatkan oleh seorang pegawai untuk memperoleh hasil kerja yang optimal (Suharsaputra dalam Iskandar, 2013). Motivasi sebagai prediktor kinerja (Ankli \& Palliam, 2012). Kinerja yang memadai salah satunya ditandai dengan adanya prestasi. Dimensi dari kinerja adalah kuantitas kerja, kualitas kerja, keandalan, dan sikap (Pujiyati, 2019). Permasalahan penelitian ini adalah masih adanya guru sertifikasi yang belum membuat perencanaan pembelajaran secara rutin, kurang bergairah dalam mengajar, kurang inovatif dalam pembelajarannya, ketika dilakukan evaluasi guru sertifikasi oleh pengawas masih ada guru yang sudah bersertifikat namun administrasi pembelajarannya belum lengkap, hal ini menandakan bahwa masih adanya sejumlah guru yang sudah bersertifikat namun belum mampu meningkatkan kinerjanya menjadi profesional seperti yang diharapkan sesuai dengan undang-undang tentang guru dan dosen.

Motivasi adalah perangkat kekuatan energi (Pujiyati, 2019) dan satu dari strategi retensi SDM, bahkan harus diawali sejak tahapan atau fase dimana, institusi merekrut calon SDM yang layak dan berkomitmen tinggi melalui proses rekrutmen dan seleksi (Nasir, dkk: 2020). Faktor-faktor yang mempengaruhi kinerja terhadap motivasi diantaranya adalah gaji, pekerjaan, rekan kerja, penghargaan (Bahri \& Nisa, 2017). Kenyataannya, dijumpai motivasi yang rendah yaitu masih adanya guru bersertifikasi yang enggan untuk mengikuti kegiatan pengembangan diri, seperti Kelompok Kerja Guru (KKG), workshop, atau seminar pendidikan.

Tujuan penelitian ini adalah untuk mengetahui korelasi antara sertifikasi guru, motivasi kerja guru, dan kinerja guru di Sekolah Dasar Negeri Kecamatan Wanasari Kabupaten Brebes.

\section{Kinerja Guru}

Kinerja adalah keluaran yang dihasilkan oleh fungsi-fungsi atau indikatorindikator suatu pekerjaan atau suatu profesi dalam waktu tertentu (Wirawan, 
2009. Kinerja adalah apa yang dapat dikerjakan oleh seseorang sesuai dengan tugas dan fungsinya, apabila seorang guru, maka kinerjanya adalah kemampuan mengajar dan uasaha dalam membuat perencanaan pembelajaran selama aktivitas pembelajaran. (Gilbert dalam Notoatmojo, 2009). Hasibuan (2001) dikutip oleh Nurchasanah (Jurnal MP, 2012) mengemukakan bahwa kinerja seseorang merupakan kombinasi dari kemampuan, usaha dan kesempatan yang dapat dinilai dari hasil kerjanya. Kinerja dimaknai sebagai kemampuan kerja yang dilihat dari tingkat pencapaian atau penyelesaian tugas (Dedeh, dkk. 2010).

Kinerja adalah hasil kerja secara kualitas dan kuantitas yang dicapai oleh seorang pegawai dalam melaksanakan tugasnya sesuai dengan tanggungjawab yang diberikan kepadanya. Tinggi rendahnya kinerja pekerja berkaitan erat dengan sistem pemberian penghargaan yang diterapkan oleh lembaga atau organisasi tempat mereka bekerja. Pemberian penghargaan yang tidak tepat dapat berpengaruh terhadap peningkatan kinerja seseorang. (Mangkunegara, 2013). Hamzah B. Uno dan Nina Lamatenggo (2012) kinerja: (1) kualitas kerja, (2) kecepatan atau ketepatan kerja, (3) inisiatif dalam bekerja,(4) kemampuan dalam bekerja, dan (5) kemampuan mengkomunikasikan pekerjaan.

\section{Motivasi Kerja}

Motivasi adalah keadaan diri seseorang (inner state) yang mendorong untuk menyalurkan perilaku ke arah tujuan (Koontz, O'Donnell, Weihrich, 1989 dalam Eros, 2014). Potensi bekerja di dalam tubuh manusia ibarat generator. Untuk menggerakkan sebuah sistem dengan energi tertentu, generator memerlukan bahan bakar atau energi sebagai pembangkit (Danim, 2008). Analogi ini mengiring kita pada pemikiran bahwa usaha memotivasi manusia dimulai dari pesonalia dan kelompok tertentu. Herlambang (2014) memberikan penjelasan bahwa motivasi yang hebat adalah motivasi yang mengarahkan motivasi individu untuk bergerak bersama dengan motivasi atau semangat organisasi. Hal ini tidak akan memberikan beban sebuah pekerjaan dan akan memberikan saling keuntungan antara individu dengan organisasi (win-win solution).

Luthans (1981) dalam Herlambang (2014:66-68) mengemukakan faktorfaktor yang mempengaruhi perubahan kekuatan motivasi, disebabkan oleh: kepuasan kebutuhan, terhalangnya kepuasan, perbedaan kognisi, frustasi, kekuatan motivasi yang bertambah.

\section{Sertifikasi Guru}

Panjang karir, jumlah karir sebelumnya, dan relevansi karir dengan bidang studi tidak berhubungan dengan kualitas pengajaran (Paredes Scribner \& Akiba, 2010). Namun sertifikasi, setiap guru yang memiliki standar sertifikasi memiliki dampak positif yang signifikan secara statistik terhadap nilai ujian siswa dibandingkan dengan guru yang tidak memiliki sertifikasi atau tidak tersertifikasi di bidang mata pelajaran mereka (Goldhaber \& Brewer, 2000). Sertifikasi muncul tahun 1960 diawali dari konferensi Teacher Education \& Professional Standard (TEFS) di San Diego, California (https://doi.org/10.2307/3389492). Dasar hukum 
pelaksanaan sertifikasi guru di Indonesia yaitu Undang-Undang RI No. 20 Tahun 2003 tentang Guru dan Dosen dan undang- undang RI No. 14 Tahun 2003 tentang Sisdiknas pasal 42 ayat 1 yaitu bahwa guru harus memiliki kualifikasi minimum dan sertifikasi sesuai dengan jenjang kewenangan mengajar, sehat jasmani dan rohani, serta memiliki kemampuan untuk mewujudkan tujuan pendidikan nasional. Amanat ini kemudian dipertegas dalam Undang-Undang No. 14 Tahun 2005 tentang Guru dan Dosen pasal 8 yang menyatakan bahwa guru wajib memiliki kualifikasi akademik, kompetensi, sertifikat pendidik, sehat jasmani dan rohani serta memliki kemampuan untuk mewujudkan tujuan pendidikan nasional. Sementara pasal 11 mengatakan bahwa sertifikat pendidik diberikan kepada pendidik yang telah memenuhi persyaratan.

Permendiknas No: 18 Tahun 2007 tentang Sertifikasi Guru Dalam Jabatan menyatakan bahwa 4 kompetensi guru profesional ini dapat diukur melalui komponen-komponen sebagai berikut (1) kualifikasi akademik; (2) pendidikan dan pelatihan; (3) pengalaman mengajar; (4) perencanaan dan pelaksanaan pembelajaran; (5) penilaian dari atasan dan pengawas; (6) prestasi akademik; (7) karya pengembangan profesi; (8) keikutsertaan dalam forum ilmiah; (9) pengalaman organisasi di bidang ke-pendidikan dan sosial; dan (10) peng-hargaan yang relevan dengan bidang pendidikan.

\section{METODE PENELITIAN}

Penelitian ini menggunakan pendekatan kuantitatif dengan metode deskriptif. Populasi dalam penelitian ini adalah seluruh guru Sekolah Dasar Negeri di Sekolah Binaan Wilayah Selatan Kecamatan Wanasari yang sudah bersertifikasi yaitu sebanyak 45 guru yang berasal dari 18 Sekolah.

Teknik pengambilan sampel didasarkan pada Probability Sampling yaitu teknik pengambilan sampel yang memberikan peluang atau kesempatan sama bagi setiap unsur atau anggota populasi yang dipilih menjadi sampel. Namun karena jumlah populasi kurang dari 100 yaitu 45 orang, maka semua anggota dijadikan sebagai sampel atau objek penelitian.

Teknik pengumpulan data yang digunakan selain studi dokumen adalah melalui angket dengan menggunakan skala Likert yaitu,

$$
\begin{array}{ll}
\mathrm{A} & =\text { sangat setuju (SS) diberikan skor } 5, \\
\mathrm{~B} & =\text { setuju (S), diberikan skor } 4, \\
\mathrm{C} & =\text { kurang setuju (KS), diberikan skor } 3, \\
\mathrm{D} & =\text { tidak setuju (TS), diberikan skor } 2, \text { dan } \\
\mathrm{E} & =\text { sangat tidak setuju (STS), diberikan skor } 1 .
\end{array}
$$

Kisi-kisi kinerja guru pada penelitian ini adalah sebagai berikut Uno \& Lamatenggo (2012); Hasanah, Fattah, \& Prihatin (2010); (1) kualitas kerja, (2) kecepatan atau ketepatan kerja, (3) inisiatif dalam bekerja (4) kemampuan dalam bekerja, dan (5) kemampuan mengkomunikasikan pekerjaan.

Kisi-kisi motivasi kerja guru pada penelitian ini adalah sebagai berikut (Robbins dalam Ardiana, 2017) :(1) dimensi dorongan internal, dan (2) dimensi 
dorongan eksternal. Kisi-kisi sertifikasi guru pada penelitian ini adalah sebagai berikut (Permendiknas, No. 18 Tahun 2007): (1) memiliki kualifikasi akademik, (2) kompetensi, (3) sertifikat pendidik, sehat jasmani dan rohani serta(4) memliki kemampuan untuk mewujudkan tujuan pendidikan nasional.

\section{HASIL PENELITIAN DAN PEMBAHASAN}

\section{Korelasi Sertifikasi Guru dengan Kinerja Guru}

Dari hasil penelitian ditemukan ada korelasi atau hubungan antara variabel sertifikasi guru dengan kinerja guru. Ini dibuktikan dari hasil analisis data yang dilakukan peneliti yaitu sertifikasi guru berkorelasi terhadap kinerja guru sebesar $67,0 \%$ dan sisanya sebesar 33,0\% ditentukan oleh faktor lain. Hasil ini berarti apabila sertifikasi guru terlaksana dengan baik dan diikuti dengan niat yang positif, maka ke depannya akan mampu meningkatkan kinerja guru menjadi lebih baik dari sebelumnya. Hasil penelitian ini sejalan dengan penelitian Murwati (2012) dengan judul Pengaruh sertifikasi profesi guru terhadap motivasi kerja dan kinerja guru di smk negeri se-Surakarta. Hasil temuannya adalah terdapat pengaruh sertifikasi profesi guru terhadap kinerja. Penelitian sebelumnya oleh Istiarini \& Sukanti (2012), dengan judul Pengaruh Sertifikasi Guru dan Motivasi Kerja Guru Terhadap Kinerja Guru SMA Negeri 1 Sentolo Kabupaten Kulon Progo Tahun 2012. Temuan penelitian adalah terdapat pengaruh positif dan signifikan Sertifikasi Guru terhadap Kinerja Guru SMA Negeri 1 Sentolo Kabupaten Kulon Progodengan koefisien korelasi ( $r$ ) 0,410, koefisien determinasi ( $r 2$ ) 0,618, dan harga t hitung 2,952l ebih besar dari tabel 1,99. Temuan ini mencari pengaruh, sementara peneliti mencari korelasi. Hasil penelitian lainnya oleh Zulkifli, Darmawan, \& Sutrisno, 2014). Judul penelitian adalah Motivasi Kerja, Sertifikasi, Kesejahteraan dan Kinerja Guru. Hasil penelitian menyatakan motivasi dan sertifikasi memegang peranan penting dalam upaya peningkatan kesejahteraan dan kinerja guru. Kinerja guru dapat diprediksi melalui kesejahteraan guru.

\section{Korelasi Motivasi Kerja dengan Kinerja Guru}

Hasil penelitian menunjukkan ada korelasi atau hubungan antara variabel motivasi kerja dengan kinerja guru. Ini dibuktikan dari hasil analisis data yang dilakukan peneliti bahwa motivasi kerja guru berkorelasi dengan kinerja guru sebesar $24,0 \%$ dan sisanya sebesar $76,0 \%$ ditentukan oleh faktor lain. Dengan kata lain, semakin baik motivasi kerjanya, akan semakin baik dan meningkat kinerja guru.

Hasil penelitian ini sejalan dengan penelitian Hasibuan (2018) dengan judul Pengaruh Kepemimpinan, Lingkungan Kerja dan Motivasi Kerja Terhadap Kinerja, dengan temuan penelitian bahwa motivasi kerja berpengaruh positif dan signifikan terhadap kinerja. Lebih lanjut, pencapaian kinerja guru (Deswita \& Ario; 2020) dapat diukur dari keberhasilan pembelajaran yang mereka lakukan di dalam kelas. 


\section{Korelasi Sertifikasi dan Motivasi Kerja secara bersama-sama dengan Kinerja Guru}

Hasil penelitian menunjukkan bahwa sertifikasi guru dan motivasi kerja guru secara bersama-sama ada korelasi terhadap kinerja guru sebesar $78,5 \%$ dan sisanya sebesar $21,5 \%$ ditentukan oleh faktor lain. Hasil penelitian ini sejalan dengan pendapat Murwati (2012). Judl penelitian adalah "Pengaruh sertifikasi profesi guru terhadap motivasi kerja dan kinerja guru di smk negeri seSurakarta". Temuan penelitian bahwa sertifikasi profesi guru berpengaruh terhadap motivasi kerja dan kinerja guru di SMK Negeri Se-Surakarta.

\section{SIMPULAN}

Terdapat korelasi signifikan sertifikasi guru dengan kinerja guru di Sekbin wilayah selatan kecamatan Wanasari. Jika melihat dari besarnya korelasi yang diberikan maka dapat diambil asumsi bahwa guru di Sekbin wilayah selatan kecamatan Wanasari sudah mampu meningkatkan kinerja mereka sebagai dampak dari sertifikasi yang telah mereka ikuti sebagai tuntutan untuk menjadi professional setelah bersertifikat meskipun pada masa pandemi covid-19.

Terdapat korelasi signifikan motivasi kerja guru dengan kinerja guru di Sekbin wilayah selatan kecamatan Wanasari. Jika melihat dari besarnya pengaruh yang diberikan maka dapat diambil asumsi bahwa guru di Sekbin wilayah selatan kecamatan Wanasari belum memiliki motivasi yang tinggi untuk meningkatkan kinerja mereka dengan maksimal.

Terdapat korelasi signifikan secara bersama-sama sertifikasi guru dan motivasi kerja guru dengan kinerja guru di Sekbin wilayah selatan kecamatan Wanasari. Untuk itu, guru yang sudah bersertifikat atau sertifikasi dituntut untuk benar-benar professional dan bekerja lebih baik dari sebelumnya atau dari guru yang belum bersertifikat atau sertifikasi, sehingga guru yang sudah sertifikasi semakin meningkatkan kinerjanya atau sebagai tuntutan.

\section{UCAPAN TERIMAKASIH}

Ucapan terimakasih penulis berikan kepada seluruh pihak yang telah berkontribusi, baik secara material maupun non-material atas tersusunnya artikel ini. Tim penulis juga memberikan penghargaan yang setinggi-tinggi kepada editorial dan reviewer Journal of Education and Teaching (JET), FKIP Universitas Muhammadiyah Kendari.

\section{DAFTAR PUSTAKA}

Ankli, R. E., \& Palliam, R. (2012). Enabling a motivated workforce: exploring the sources of motivation. Development and Learning in Organizations: An International Journal.

Ardiana, T. E. (2017). Pengaruh motivasi kerja guru terhadap kinerja guru akuntansi SMK di Kota Madiun. Jurnal Akuntansi dan Pajak, 17(02).

Bahri, S., \& Nisa, Y. C. (2017). Pengaruh Pengembangan Karir Dan Motivasi Kerja Terhadap Kepuasan Kerja Karyawan. Jurnal IImiah Manajemen dan Bisnis, 18(1), 9-15. 
Debbarma, I., \& Durai, T. (2021). Educational disruption: Impact of COVID-19 on students from the Northeast states of India. Children and Youth Services Review, 120, 105769.

Deswita, H., \& Ario, M. (2020). Evaluasi Pembelajaran: Kemampuan Koneksi Matematis Siswa SMPN 1 dan SMPN 2 Kepenuhan. Journal of Education and Teaching (JET), 1(1), 33-39. https://doi.org/10.51454/jet.v1i1.14

Eros, E. (2014). Pengaruh motivasi dan kedisiplinan kerja guru terhadap kinerja guru di smp negeri kecamatan brebes kabupaten brebes jawa tengah. Jurnal Administrasi Publik dan Birokrasi, 1(1), 72280.

Goldhaber, D. D., \& Brewer, D. J. (2000). Does teacher certification matter? High school teacher certification status and student achievement. Educational evaluation and policy analysis, 22(2), 129-145.

Hasanah, D. S., Fattah, N., \& Prihatin, E. (2010). Pengaruh Pendidikan Latihan (Diklat) kepemimpinan guru dan iklim kerja terhadap kinerja guru sekolah dasar se Kecamatan Babakancikao Kabupaten Purwakarta. Jurnal Penelitian Pendidikan, 11(2), 90-105.

Hasibuan, S. M. (2018). Pengaruh Kepemimpinan, Lingkungan Kerja dan Motivasi Kerja terhadap Kinerja. Maneggio: Jurnal IImiah Magister Manajemen, 1(1), 71-80.

Herlambang, S. (2014). Perilaku Organisasi. Cet. Pertama. Yogyakarta: Pustaka Baru.

Iskandar, U. (2013). Kepemimpinan kepala sekolah dalam peningkatan kinerja guru. Jurnal Visi Ilmu Pendidikan, 10(1).

Istiarini, R., \& Sukanti, S. (2012). Pengaruh Sertifikasi Guru dan Motivasi Kerja Guru Terhadap Kinerja Guru SMA Negeri 1 Sentolo Kabupaten Kulon Progo Tahun 2012. Jurnal Pendidikan Akuntansi Indonesia, 10(1).

Kartowagiran, B. (2011). Kinerja guru profesional (Guru pasca sertifikasi). Jurnal Cakrawala Pendidikan, 3(3).

Murwati, H. (2012). Pengaruh sertifikasi profesi guru terhadap motivasi kerja dan kinerja guru di smk negeri se-Surakarta.

Nasir, Adam, M. Rahmawati, Arfin, Mujiati, \& R. Titin. 2020. Manajemen Sumber Daya Manusia: Pengadaan dan Retensi SDM Diperguruan Tinggi Swasta (Teori dan Praktek). Bandung: PT Alfabeta. https://www.researchgate.net/publication/342522445.

Paredes Scribner, J., \& Akiba, M. (2010). Exploring the relationship between prior career experience and instructional quality among mathematics and science teachers in alternative teacher certification programs. Educational Policy, 24(4), 602-627.

PERMENDIKNAS Nomor 18 Tahun 2007 tentang Sertifikasi Guru dalam Jabatan.

Pujiyati, W. (2019). Kepemimpinan dan Perilaku Organisasi, Yogyakarta: K-Media

Review Article, Volume: 47 issue: 5, page(s): 101-101, Issue published: April 1, 1961

Sudarwan, D. (2008). Kinerja Staf dan Organisasi. Bandung: CV Pustaka Setia.

Sujanto, Bedjo. (2009). Cara Efektif Menuju Setifikasi Guru. Jakarta: Raih Asa Sukses 
Undang-Undang RI No. 20 Tahun 2003 tentang Guru dan Dosen

Uno, H.B., dan Lamatenggo, N. (2012). Teori Kinerja dan Pengukurannya, Jakarta: PT. Bumi Aksara

Wirawan. (2009). Evaluasi Kinerja Sumber Daya Manusia. Jakarta: Salemba Empat

Zulkifli, M., Darmawan, A., \& Sutrisno, E. (2014). Motivasi Kerja, Sertifikasi, Kesejahteraan dan Kinerja Guru. Persona: Jurnal Psikologi Indonesia, $3(02)$. 